\title{
The Effect of Multiliteracy Learning Models On Elementary Students' Critical Thinking Skill and Students' Curiosity Attitudes
}

\author{
Eli Hermawati', Mia Zultrianti Sari², Aan Nurhasanah ${ }^{3}$ \\ Faculty of Education, Kuningan University, Indonesia
}

\{eli.hermawati@uniku.ac.id\}

\begin{abstract}
This research is motivated by the low ability of students to think critically in science subjects and the attitude of students' curiosity towards learning which has a major influence on the success of achieving learning objectives. The purpose of this study was to determine (1) the effect of the Multiliteracy learning model on elementary students' critical thinking skill, (2) the effect of the Multiliteracy learning model on students' curiosity attitudes. The method uses Quasi Experimental, while the research design uses the Non Equivalent Control Group Design. The dependent variable in this study is the student's critical thinking ability and students' curiosity attitude. While the independent variable is the multilateration model. The subjects of this study were 20 students of grade VA and 20 students of VB at SD Negeri 1 Ciporang. This research data collection using objective tests in the form of essays and observations. The results showed (1) there was an effect of the multilateration learning model on the critical thinking skills of elementary school students, (2) there was an effect of the multilateration learning model on the curiosity of elementary school students. This is indicated by the calculation result tvalue $>$ ttable. So it can be concluded that using the multilateration model can have a significant effect on the critical thinking skills and curiosity of students compared to those who do not use the multilateration model
\end{abstract}

Keywords: Multiliteracy Model; Critical Thinking Skill; Student's Curiosity Attitude; Science

\section{Introduction}

According to Stobaugh (Julianda et al., 2018) suggests that critical thinking is a process that is carried out systematically that allows students to formulate and evaluate their own beliefs and opinions and not memorize them. This critical thinking ability is an ability that can be said to be the most difficult if a person is unable to develop it. This critical thinking ability is not just thinking and then pouring a statement or opinion into a writing without including strong reasons and evidence about the statement, but pouring a statement or opinion accompanied by a strong evidence and reasons for the statement he has made. Students who do not develop their critical thinking skills will experience difficulty in expressing an opinion about something. Because this critical thinking ability requires thoughts that have a reason and factual data. Therefore, critical thinking skills need to be developed from an early age so that learning can be absorbed properly. 
But in fact, the problem that occurs to students who are at this level of primary school education is that students still seem slow in their critical thinking skills so that they seem to lack understanding of the information provided by their teachers in the learning process. This can be due to several factors, such as the environmental factors where the learning is not supportive, the application of the learning model is still less varied. For example, sometimes students do not like learning that only convey a material, so that students become easily bored, joke a lot, etc., all of which can have an impact on students' lack of curiosity, there are still students who are embarrassed to express a question or the student does not understand the information he conveys. Then, students are still unable to solve a problem in the learning process, are less able to make a decision or draw a conclusion on what the teacher has said.

Therefore, it is important for students to develop critical thinking skills in order to find the truth that actually fits the facts. Not all of the learning carried out in schools can improve students' critical thinking skills. Sometimes the learning that is carried out also often neglects the development of students' critical thinking. In addition, students sometimes do not pay close attention to existing information, which results in students tending to receive modest information. Students become more passive and embarrassed to ask a question so that it makes students slower in accepting information conveyed by educators. Therefore, students are not used to analyzing and arguing about a subject which is all one aspect / indicator of critical thinking. In addition, there are still many indicators of student critical thinking that have not been fulfilled or can be said to be low. Based on the results of interviews conducted by researchers at SD Negeri 1 Ciporang on Friday January 24, 2020, students' critical thinking skills in the content of Natural Sciences (IPA) were still low. Below is a table of students' critical thinking skills in grade V B SD Negeri 1 Ciporang, Kuningan District, Kuningan Regency as follows.

Table 1. Percentage of Critical Thinking Ability Grade V B Students of SD Negeri 1 Ciporang Academic Year 2019/2020

\begin{tabular}{|c|c|c|c|c|c|}
\hline No & Indicators of Critical Thinking & Appear & Percentage & $\begin{array}{c}\text { Not } \\
\text { Appeared }\end{array}$ & Percentage \\
\hline 1. & $\begin{array}{l}\text { Answering questions / problems } \\
\text { contextually }\end{array}$ & 8 & $20 \%$ & 31 & $80 \%$ \\
\hline 2. & $\begin{array}{l}\text { Make observations and answer } \\
\text { according to observations }\end{array}$ & 8 & $20 \%$ & 31 & $80 \%$ \\
\hline 3. & Draw conclusions & 8 & $20 \%$ & 31 & $80 \%$ \\
\hline 4. & $\begin{array}{l}\text { Provide an understanding of the } \\
\text { problem and answer questions by } \\
\text { including logical reasons }\end{array}$ & 8 & $20 \%$ & 31 & $80 \%$ \\
\hline 5. & Provide solutions & 8 & $20 \%$ & 31 & $80 \%$ \\
\hline
\end{tabular}

Based on table 1 above, it shows that the problems faced are low students' critical thinking skills. The results of interviews with class VB teachers, the number of students who showed good critical thinking skills, namely 8 students with a percentage of $20 \%$ for class V B students. Therefore, the critical thinking skills of class VB students are still in the very low category, this is shown from the number of indicators and sub indicators of critical thinking skills are only a few that can be achieved by students. For example, making summaries, providing simple explanations, citing examples, formulating alternative solutions, the ability to provide reasons, and making fact-based judgments.

The ability to think critically will be honed when students have an attitude of curiosity about learning. As stated by Kurniawan (2013), students should have a good attitude towards the subjects they are studying. Because, a good attitude towards lessons has a major effect on 
the success of achieving learning objectives. Attitudes or behavior according to Cavendish in (Fatonah \& Prasetyo, 2014), describe that behavior that is adapted and applied to special situations can be in the form of interests / concerns, appreciation, likes, dislikes, opinions, values, and ideas of a person Curiosity (Mustari, 2011: 103), namely attitudes and actions that always seek to know more deeply and broadly from what they have learned, seen and heard. This is related to obligations towards oneself and the environment. Curiosity or curiosity (Mustari, 2011: 104) is an emotion associated with natural prying behavior such as exploration, investigation and learning.

Curiosity is one part of the 18 national character values contained in character education which includes value education, character education, moral education, character education which aims to develop the ability of students to make good and bad decisions, maintain what is good. and realize that kindness in everyday life with all my heart. These character values are a number of character-forming values which are the result of an empirical study of the Curriculum Center (Samani \& Hariyanto, 2012). Based on the above problems, it is necessary to have a learning model that can support to provide solutions to improve students 'critical thinking skills and increase students' curiosity. In this case, the model used must of course be meaningful, fun and provide easy understanding for students to observe, and can increase student activity in the learning process.

The multiliterative learning model is learning that is carried out in which a person can increase his / her ability to express an idea or idea which can also be a question and provide a logical problem solving. According to Ginanjar \& Widayanti, (2019), the multilateration learning model is a learning process that places the ability to read, write, listen and speak as efficiently as possible, of course, to improve thinking skills, including the ability to criticize, analyze, and evaluate information from various sources and the ability to communicate that information. In other words, students must be able to respond to a certain phenomenon based on the full concept of knowledge, not separate or divided knowledge.

The use of multiliterative learning models in the implementation of learning activities carried out by the teacher is intended to provide a stimulus or stimulus to students so that students are able to analyze a reading so that it raises a curiosity about the reading so that it makes it want to ask friends and students can conclude answers from their friends until finally the students can present the reading in their own way. The good thing is in applying this multilateration learning model the teacher must provide a reading text first for students to learn and the teacher must continue to guide or rectify students if they experience an error while having a discussion. This learning model is certainly beneficial for students to mentally train them in expressing their opinions.

\section{Method}

The type of research to be used is experimental research with quantitative research types. According to (Sugiyono, 2018: 107) experimental research can be interpreted as a research method used to find the effect of certain treatments on other treatments under controlled conditions. Where the method to be used is the Quasi Experimental method. The Quasi Experimental Design form chosen by the researcher is Nonequivalent Control Group Design. Nonequivalent Control Group Design has two groups selected, namely the experimental class and the control class. The experimental class is a class that in the learning process uses the Multiliteration Learning Model and the control class is a class that in the learning process does 
not use a multiliterative learning model but uses a learning method or model that is usually used by the teacher. According to Arikunto (2015: 86) this design can be described as follows:

Table 2. Research Design

\begin{tabular}{cccc}
\hline Group & Pretest & Treatment & Posttest \\
\hline Experiment & $\mathrm{O}_{1}$ & $\mathrm{X}$ & $\mathrm{O}_{2}$ \\
Control & $\mathrm{O}_{3}$ & - & $\mathrm{O}_{4}$ \\
\hline
\end{tabular}

\subsection{Data Collection Technique}

Data collection techniques are used to obtain the required data. In carrying out this research, researchers used the following data collection techniques:

\subsubsection{Test}

The test in this study used a written test in the form of an essay. Where this essay test is expected to be able to improve students' critical thinking skills to be more developed. The test was carried out at the pretest and posttest. Pretest or initial test is given to students with the aim of knowing the initial ability of the research subject (students). While the posttest or final test is given to students with the aim of seeing changes or improvements in students' critical thinking skills after using the multilateration learning model.

\subsubsection{Observation}

Observations in this study were used to see the curiosity of students after using the multilateration learning model. This research will be conducted at SD Negeri 1 Ciporang, Kuningan District, Kuningan Regency, West Java. The research subjects were students in class V at SD Negeri 1 Ciporang, class V A with 20 students and class V B with 20 students, where these classes will get different treatment. Class V B will get the Multilateration Learning Model treatment as the experimental class and class V A will get treatment by not using the multilateration learning model as the control class.

Table 3. Research Subject

\begin{tabular}{ccc}
\hline Group & Class & The Number of Students \\
\hline Experiment & V B & 20 Orang \\
Control & V A & 20 Orang \\
\hline
\end{tabular}

\section{Result and Discussion}

\subsection{Data of Pretest and Posttest Results}

The tests carried out in this study conducted two tests, namely the initial skills test (pretest) and the final skills test (posttest). The initial test is a test that is carried out before using a treatment or treatment. Meanwhile, the final test (posttest) is a test that is carried out after using a treatment or treatment. The data obtained from the results of the pretest and posttest in the experimental class (VA) and control class (VB) are presented in table form as follows:

Table 4. Pretest Result Data Experiment Class and Control Class

\begin{tabular}{llllll}
\hline & Class & N & Mean & Std. Deviation & Std. Error Mean \\
\hline Value Pretest & Experiment & 20 & 57,25 & 10,721 & 2,397 \\
& Control & 20 & 50,95 & 10,546 & 2,358 \\
\hline
\end{tabular}

The pretest result data is also presented in the form of a diagram as follows: 


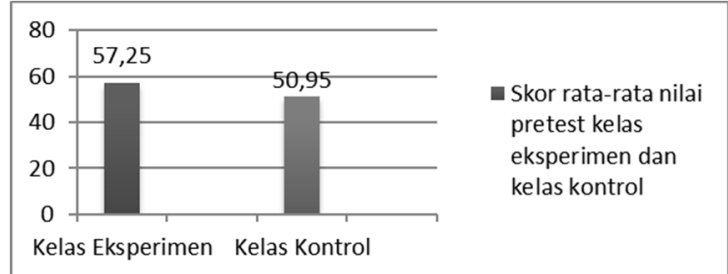

Fig 1. Data Diagram of Pretest Results for Experiment Class and Control Class

Based on Figure 1, the data diagram of the pretest results of the experimental class and control class shows a difference that is not much different. The data also shows that the two classes need to be provided with assistance in learning. This is based on the fact that the research subjects obtained scores that had not reached the specified minimum completeness criteria (KKM) of 70. After knowing the students' initial abilities related to critical thinking skills and curiosity attitudes as well as doing treatment in the learning process. The next step is to do the final test (posttest). Following are the results of the final (posttest) test presented in tabular form:

Table 5. Posttest Result Data Experiment Class and Control Class

\begin{tabular}{c|c|c|c|c|c}
\hline & Class & $\mathrm{N}$ & Mean & Std. Deviation & Std. Error Mean \\
\cline { 1 - 2 } Value_Postttest & Experiment & 20 & 87,15 & 7,088 & 1,585 \\
& Control & 20 & 82,15 & 5,451 & 1,219 \\
\hline
\end{tabular}

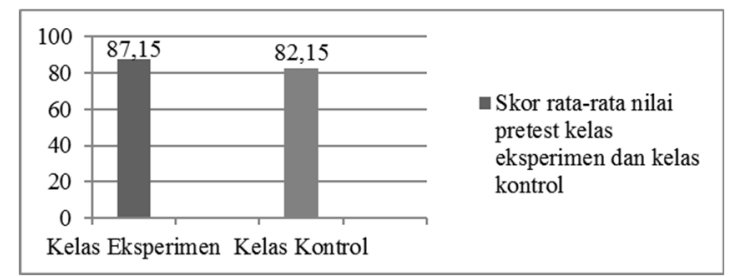

Fig 2. Posttest Result Data Diagram for Experiment Class and Control Class

\subsection{Description of $\mathrm{N}$-gain data}

This calculation aims to determine the student's increase in critical thinking skills and curiosity. The data obtained were processed in SPSS for windows version 22.00 and produced the following data:

Table 6. N-gain Score for Experiment Class and Control Class

\begin{tabular}{cccccc}
\hline Class & Pretest & Posttest & Gain & N-Gain & Criteria \\
\hline Experiment & 57,25 & 87,17 & 29,92 & 0,72 & High \\
Control & 51,00 & 82,25 & 31,25 & 0,63 & Moderate \\
\hline
\end{tabular}

Based on the results of the data obtained, it is known that the experimental class that uses the multiliteration learning model has a high increase from the control class related to critical thinking skills and student curiosity attitudes. This increase can be seen in the graph below. 


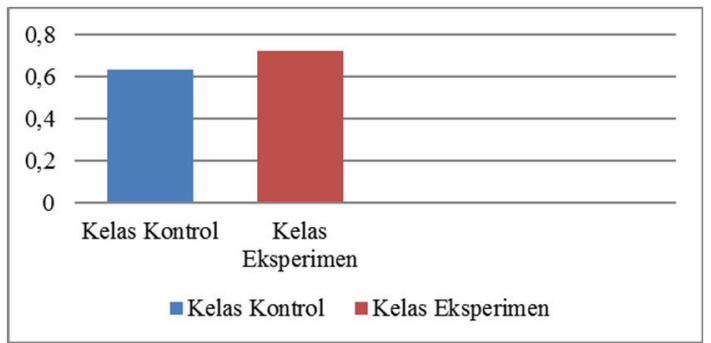

Fig 3. N-Gain Chart for Control Class and Experiment Class

\subsection{Observation Result Data}

Based on the results of observations regarding the curiosity of grade V students at SDN Ciporang in the learning process using Multiliteracy can be seen in the table below:

\begin{tabular}{|c|c|c|c|c|c|}
\hline No & Student's Name & Amount & Score & P \% & Criteria \\
\hline 1 & Akbar Muhamad & 20 & 100 & $100 \%$ & Very High \\
\hline 2 & Derry Aditya Putra & 13 & 65 & $65 \%$ & High \\
\hline 3 & Harlan H F & 13 & 65 & $65 \%$ & High \\
\hline 4 & Luthfiana Nazifa H & 15 & 75 & $75 \%$ & High \\
\hline 5 & Marsya Kamila & 18 & 90 & $90 \%$ & Very High \\
\hline 6 & Muhamad Alvin F & 10 & 50 & $50 \%$ & Moderate \\
\hline 7 & Muhamad Damian & 15 & 75 & $75 \%$ & High \\
\hline 8 & Muhammad Fadhel & 15 & 75 & $75 \%$ & High \\
\hline 9 & Muhammad Keano & 13 & 65 & $65 \%$ & High \\
\hline 10 & Nabila Anindya & 15 & 75 & $75 \%$ & High \\
\hline 11 & Naila Zahriyatun & 13 & 65 & $65 \%$ & High \\
\hline 12 & Neisya Nurfazrie & 17 & 85 & $85 \%$ & Very High \\
\hline 13 & Raffa Keandra & 20 & 100 & $100 \%$ & Very High \\
\hline 14 & Reva Alvia Salma & 19 & 95 & $95 \%$ & Very High \\
\hline 15 & Reyva Naura & 20 & 100 & $100 \%$ & Very High \\
\hline 16 & Rizma Aulia A & 13 & 65 & $65 \%$ & High \\
\hline 17 & Siti Affrah Zahira & 13 & 65 & $65 \%$ & High \\
\hline 18 & Yusuf Ridwan & 15 & 75 & $75 \%$ & High \\
\hline 19 & Zaskia Anaya Putri & 20 & 100 & $100 \%$ & Very High \\
\hline \multirow[t]{2}{*}{20} & Zia Putri Amalia & 20 & 100 & $100 \%$ & Very High \\
\hline & Amount & $\mathbf{P}$ & 1585 & $79 \%$ & High \\
\hline
\end{tabular}

Based on table 7, there are 8 people who show a very high curiosity attitude. While 12 other people showed an attitude of high curiosity. Of the 20 grade V SDN Ciporang students got a score of 1585 with a percentage of $79 \%$ having high criteria. So it can be concluded that the curiosity attitude of class V SDN Ciporang students by using multiliterative learning is high.

\subsection{Discussion}

Critical thinking skills and curiosity are important things for students to master. Therefore, we need a breakthrough in learning which is expected to be able to hone students' critical thinking skills and curiosity. So in this study will use a multiliterative learning model which is expected to be able to help the problems that occur. The multiliterative learning model is a skill in using a variety of ways to express and understand ideas and information using conventional text forms as well as innovative text, symbols, and multimedia. Abidin (2018: 51). Literacy which means reading. Reading, of course, must have an understanding related to 
what is being read. Therefore, this multiliteration helps a person in studying a text or reading so that it is not just reading activities.

This study will conduct two tests, namely the initial test (pretest) and the final test (posttest). This test is carried out on research subjects who will later become an overview of this research. The initial test is a test before the treatment is given, while the final test is a test after the treatment is given. The preliminary and final test results obtained from the pretest data showed that the experimental class before using the multiliteration learning model, of 20 students obtained a class average score of 57.25 with a standard deviation of 10.721 . While the control class before being given treatment in the form of a learning model commonly used by teachers in schools obtained an average value of 50.95 from 20 students with a standard deviation of 10.546. The results of the two classes can be seen that the research subjects have initial abilities that are not much different.

While the final test results in the experimental class of as many as 20 students obtained a class average score of 87.15 with a standard deviation of 7.088 . While the control class after being given treatment in the form of a learning model commonly used by teachers in schools obtained an average value of 82.15 from 20 students with a standard deviation of 5.451. Departing from these results, it shows that the experimental class that uses the multiliteration learning model has a higher increase than the control class. This is evidenced by the class average result of 87.15 .

The data was then tested for data analysis, while the first analysis test was related to normality testing using the One-Sample K-S statistical test in the SPSS version 22.00 program. The results of the pretest data normality test showed that the experimental class obtained a significance of 0.200 , which means $0.200>0.05$. Meanwhile, the control class obtained a significance of 0.200 , which means $0.200>0.05$. From the data obtained, it proves that the pretest value data on the research subject shows data that is normally distributed. The results of the posttest normality test showed that the experimental class obtained a significance of 0.136 , which means it was $0.136>0.05$.

Meanwhile, the control class obtained a significance value of $0.004>0.05$. This shows that the data obtained on the posttest score of the control class is not normally distributed. Data that has been tested in the normality test shows that the data is not normally distributed only in the control class posttest. These results are evidenced by the results of the normality test at the Kolmogorov-Smirnov output for the Asymptotic Coefficient Sig $>$ of the specified alpha value, namely $5 \%(0.05)$. The next test is to test homogeneity using the Lilliefors Significance test, while the results obtained show that the pretest homogeneity test obtained a significance of 0.692 , meaning $0.692>0.05$. This shows that the pretest value data, both in the experimental class and in the control class, is homogeneous (same variant). This result is evidenced by a probability value $>0.05$. Then in the posttest homogeneity test it is known to obtain a significance of 0.111 , meaning $0.111>0.05$. This shows that the posttest value data, both in the experimental class and in the control class, is homogeneous (same variant). This result is evidenced by a probability value $>0.05$. The data obtained in the pretest and posttest homogeneity test both showed homogeneous results. These results are evidenced by the significance in each class obtaining more than 0.05 .

After conducting the statistical prerequisite test, the next test is to test the hypothesis. This test aims to determine the effect of using a multiliterative learning model on students' critical thinking skills and curiosity. The results of the data obtained indicate that the tcount in the posttest group is 2.501 and the significance value is 0.017 . These results indicate that $0.017<$ 0.05 , which means that the significance value of 0.017 is less than 0.05 . Based on the criteria, it can be stated that $\mathrm{H} 0$ is rejected and $\mathrm{H} 1$ is accepted. These results can be explained that 
there is an effect of the multiliterative learning model on critical thinking skills and curiosity attitudes of fifth grade elementary school students at SD Negeri 1 Ciporang.

The next test is to find out whether there is an increase after doing treatment on the research subject. The data obtained comes from the accumulated N-Gain value that has been previously calculated. The results obtained are tcount of 11,754 and a significance value of 0,000 . These results indicate that $0.000<0.05$, which means that the significance value of 0.000 is less than 0.05 . Based on the criteria, it can be stated that $\mathrm{H} 0$ is rejected and $\mathrm{H} 1$ is accepted. These results can be explained that there is an effect of increasing the Multiliteracy learning model on critical thinking skills and curiosity attitudes of fifth grade elementary school students at SD Negeri 1 Ciporang.

This gain test aims to determine how much improvement there is in this study. The results of the N-Gain test in the experimental class obtained a value of 0.72 and the results of the NGain test in the control class obtained a value of 0.63 . These results are then entered into the $\mathrm{N}$-Gain criteria, it can be concluded that the increase in students 'critical thinking skills in the experimental class is in the "High" category because the final score exceeds 0.70 and the increase in students' critical thinking skills in the control class is in the "Medium" category due to the final score. less than 0.70 .

The increase in students' critical thinking skills in the experimental class occurs because it is caused by several factors, one of which is the use of the critical Multiliteracy model. With this critical multiliteration model, students can develop their initial ability to think critically in the learning process by doing a stimulus first in the initial activity by giving students the opportunity to argue about the problems that are around them. In accordance with the theory expressed by Jaenudin et al., (2019) multiliterative learning is directed at multicompetence. In multiliterative learning, students do not only acquire one competency but also various competences of attitudes and character. The competencies possessed include high understanding competencies, critical thinking competencies, collaboration and communication competencies, and creative thinking competencies. In addition, this critical multiliteration model also includes a process of reading a text in which the text has been prepared by the researcher so that the text is not correct, thus students must develop their critical thinking skills by finding the truth about the text they read.

After that, students can make a work from the results of their thoughts through a picture, poster or other. In this case, students seem happy with learning to use this model because in addition to requiring more thought, students can convey their ideas or ideas through a picture or other things. It is in line with the theory put forward by Moss \& Dianne (2010) which states that multiliterative learning demands the goal that educators always help students read and relate them to various other scientific texts and make the text function as a message to obtain information (there is a response from students and teachers in the learning process) Of course, the information obtained must be in the form of factual information with a clear level of validity (Dafit et al., 2018).

Meanwhile, the results of observations regarding students' curiosity attitudes using multiliterative learning showed that there were 8 people who showed very high curiosity attitudes. While 12 other people showed an attitude of high curiosity. Of the 20 grade V SDN Ciporang students got a score of 1585 with a percentage of $79 \%$ having high criteria. So it can be concluded that the curiosity attitude of class V SDN Ciporang students by using multiliterative learning is high. If we look at the aspect of the student's curiosity, the first thing about trying to know the lesson by reading books and asking questions is $79 \%$ data with high criteria. In the aspect of observing the environment in search of new experiences, $73 \%$ of data were obtained with high criteria. Meanwhile, in the aspect of showing listening, speaking, 
reading, and writing skills, $81 \%$ of the data were obtained with very high criteria. In the aspect of not accepting something learning as boring, it shows $80 \%$ with very high criteria. And finally, in the aspect of seeing and understanding when learning to feel fun shows $84 \%$ with very high criteria. So it can be concluded that students who have good curiosity will have knowledge, and are not bored to learn.

Multiliterative learning has been shown to increase students' curiosity. This multiliterative learning is the teacher's effort to foster an attitude of curiosity by developing every learning process, encouraging children to actively participate, giving children freedom to explore, not differentiating between children and establish The use of multiliterative learning models has a positive impact on students' critical thinking in the learning process. This was proven when giving treatment to the experimental class. Students are active in the learning process by looking for clear answers to each question, are able to solve a problem by trying to find out information appropriately, are able to think and behave systematically and regularly and show an open mind and attitude.

This is in line with the criteria for critical thinking conveyed by Fahrudin (2012) which explains that critical thinking criteria include: 1) Able to formulate problem issues, including: Looking for clear answers to each question ; 2) Able to reveal the facts needed to solve a problem, including: trying to find out information accurately, using credible sources and mentioning it, understanding the original and basic objectives; 3) Being able to choose logical, relevant and accurate arguments, including: looking for reasons or arguments, trying to stay relevant to the main idea, thinking and behaving systematically and regularly by paying attention to the parts of the whole problem. 4) Be able to detect bias based on different points of view, including: looking for alternative answers, taking a stand when there is sufficient evidence to do something, seeking explanations as much as possible whenever possible. 5) Able to determine the consequences of a question taken as a decision, including: paying attention to the situation as a whole, having an open mind and attitude harmonious relationships with children.

\section{Conclusion}

The research that has been done is about "The Influence of Critical Multiliteration Model on Students' Critical Thinking Ability" class 5 in SD Negeri 1 Ciporang-Kuningan, West Java. Based on the research results and hypothesis testing in this study, the following conclusions can be drawn:

a. There is an effect of the Multiliteracy learning model on the critical thinking skills of elementary school students.

b. There is an effect of the Multiliteracy learning model on the curiosity attitude of elementary school students.

The results of the discussion can be concluded that using the multiliteration model can have a significant effect on the critical thinking skills of students who use the Multiliteracy model compared to those who do not. 


\section{References}

[1] Abidin, Y. (2018). Pembelajaran Multiliterasi (Sebuah jawaban atas tantangan pendidikan abad ke21 dalam konteks keindonesiaan). Bandung: PT Refika Aditama.

[2] Arikunto, S. (2015). Dasar-dasar Evaluasi Pendidikan. Jakarta: PT Rineka Cipta.

[3] Dafit, F., Mustika, D., \& Ain, S. Q. (2018). Efektivitas Pembelajaran Multiliterasi Terhadap Kemampuan Berpikir Kritis Siswa Sekolah Dasar Pada Materi Ekosistem. JMIE (Journal of Madrasah Ibtidaiyah Education), 2(2), 181-193. https://doi.org/10.32934/jmie.v2i2.71

[4] Fahrudin, F. (2012). Thinking Skill. (Pengantar Menuju Berpikir Kritis).

[5] Fatonah, S., \& Prasetyo, Z. . (2014). Pembelajaran Sains. Yogyakarta: Ombak.

[6] Ginanjar, A. Y., \& Widayanti, W. (2019). Penerapan Model Pembelajaran Multiliterasi Untuk Meningkatkan Kemampuan Literasi Matematis Siswa Di Sd/Mi. Primary: Jurnal Keilmuan Dan Kependidikan Dasar, 10(2), 117. https://doi.org/10.32678/primary.v10i02.1283

[7] Jaenudin, J., Puspitasari, W., \& Cahyaningsih, U. (2019). Penerapan Model Multiliterasi Untuk Meningkatkan Kemampuan Membaca Pemahaman. In Prosiding Seminar Nasional Pendidikan, $550-555$.

[8] Julianda, Widiati, U., \& Djatmika, E. T. (2018). Pengaruh Strategi Pembelajaran Inkuiri Berbasis Keterampilan Multiliterasi terhadap Kemampuan Berpikir Kritis Siswa. Jurnal Pendidikan: Teori, Penelitian, Dan Pengembangan, 2012, 460-467.

[9] Kurniawan. (2013). Pengaruh Kompetensi Pedagogik, dan Kompetensi Professional Guru. Universitas Pendidikan Indonesia: Pustaka Belajar.

[10] Moss, B., \& Dianne, L. (2010). Teaching New literacies in gradeas k-3, resources for 21st century classroom. New York: Guilford Publications.

[11] Mustari, M. (2011). Nilai Karakter: Refleksi untuk Pendidikan Karakter. Laksabang Pressindo.

[12] Samani, M., \& Hariyanto. (2012). Pendidikan Karakter: Konsep dan Model. Bandung: Remaja Rosdakarya.

[13] Sugiyono. (2018). Metode Penelitian Kuantitatif, Kualitatif dan R\&D. Bandung: Alfabeta. 